\title{
Efektifitas Kombinasi Ekstrak Buah Pare Dan Sawo Manila Sebagai Antimikroba Bakteri Salmonella Typhi Isolasi Pada Carrier Tifoid
}

\section{The Effectiveness Of Combination Of Pare And Sawo Manila as Antimicroba Of Salmonella Typhi Bacteria Isolation From Carrier Tifoid}

\author{
Awaluddin Susanto $^{1 *}$, Antofani Farhan ${ }^{2}$, Farach Khanifah ${ }^{3}$ \\ ${ }^{1,2,3}$ Program Studi Analis Kesehatan, Sekolah Tinggi Ilmu Kesehatan Insan Cendekia Medika Jombang \\ Jalan Halmahera no. 27 Kaliwungu Plandi, Jombang, JawaTimur Indonesia \\ *Corresponding author \\ Email: awwalluddins@gmail.com
}

Keyword :

Bitter gourd, extract, Manilkara zapota, Thypus Fever,
A b s t ract

Background: Salmonella typhi is the cause of typhoid fever. Carrier typhoid fever is a risk factor of typhoid fever. The absence of treatment for these carriers is still a problem. Bitter gourd and Manilkara zapota contain many active compounds that have the potential as antimicrobial including Salmonella typhi bacteria which cause typhoid. Objectif: This study aims to inhibit the growth of Salmonella typhi bacteria from the combination of bitter gourd extract and Manilkara zapota. Methods: This research is an true experimental study with a pre-post test group design control. The population was Salmonella typhi bacteria isolated from students of STIKES ICME who were diagnosed with typhoid carrier and used was incidental sampling. Testing for the inhibition of Salmonella typhi bacterial growth from carriers with typhoid sufferers was given bitter gourd and Manilkara zapota extracts with concentration 25\%, 50\%, 75\% dan 100\%.. The measurement of bacterial growth was derived from carrier stool samples and then planted on SSA media and the antimicrobial test with solid dilution method was carried out by using MHA media. Analyzed by using the ANOVA statistical test with SPSS for windows program with a confidence level of $P=0.05$. Results: Kruskal Wallis test which showed the differences between treatments significant $(p=0,018)$. Mann-Withney test was carried out with the results of the control group being significantly different from all treatment groups, as well as between treatment groups, each significantly different. Conclusion: All concentration the combination of bitter gourd and Manilkara zapota fruit extract is effective in inhibiting the growth of Salmonella typhi bacteria.

\section{Kata kunci :}

Buah pare,

Carrier Tifoid,

Ekstrak,

Salmonella typhi,

Sawo manila,

\begin{abstract}
ABSTRAK
Latar belakang: Bakteri Salmonella typhi adalah penyebab penyakit demam tifoid. Kasus carrier demam tifoid merupakan faktor resiko terjadinya outbreak demam tifoid. Belum adanya penatalaksanaan pengobatan terhadap carrier inilah yang sekarang masih menjadi permasalahan. Buah pare dan sawo manila terkandung banyak sekali senyawa aktif dan berpotensi sebagai antimikroba alami, salah satunya bakteri Salmonella typhi penyebab demam tifoid. Tujuan: Penelitian ini bertujuan untuk mengetahui kombinasi ekstrak buah sawo manila dan pare yang efektif dalam menghambat pertumbuhan bakteri Salmonella typhi. Metode: Penelitian ini true eksperimental dengan pre-post test group desain control dengan populasi bakteri Salmonella typhi hasil isolasi dari mahasiswa Program Studi Analis Kesehatan STIKes ICMe Jombang yang terdiagnosa carrier demam tifoid. Teknik sampling menggunakan incidental sampling. Pengujian penghambatan pertumbuhan bakteri Salmonella typhi dari carier demam tifoid diberikan ekstrak buah pare dan sawo manila dengan konsentrasi $25 \%, 50 \%, 75 \%$ dan $100 \%$. Pengukuran jumlah bakteri berasal dari sampel feces carier
\end{abstract}


kemudian ditanam pada media SSA dan dilakukan uji antimikroba metode dilusi padat menggunakan media MHA. Analisa data dengan uji statistik ANOVA menggunakan program SPSS for tingkat kepercayaan $\mathrm{p}=0,05$. Hasil: Hasil penelitian berdasarkan uji Kruskal Wallis menunjukkan perbedaan antar perlakuan secara signifikan $(\mathrm{p}=0.018)$. Kemudian dilakukan uji Mann Withney dengan hasil kelompok perlakuan kontrol berbeda nyata dengan semua kelompok ekstrak, begitu juga antar kelompok perlakuan masing-masing berbeda nyata. Kesimpulan: Berbagai kombinasi konsentrasi ekstrak buah pare dan sawo manila efektif menghambat bakteri Salmonella typhi.

\section{LATAR BELAKANG}

Bakteri Salmonella typhi adalah penyebab terjadinya demam tifoid. Penyakit tifus dapat ditularkan melalui makanan dan minuman yang terkontaminasi. Banyaknya jumlah penderita demam tifoid disebabkan oleh lingkunan yang kurang bersih atau tercemar, salah satu penyebabnya adalah carier penderita demam typhoid yang dapat mencemari lingkungan Karena membuang feces secara sembarangan. ${ }^{1}$

Pada feces carier masih dapat di temukan bakteri Salmonella typhi setelah satu tahun terjadi infeksi aktif, sehingga dapat menyebarkan bibit penyakit pada lingkungan. Kasus demam tifoid carrier merupakan faktor resiko terjadinya outbreak demam tifoid. Penderita tifoid yang sembuh secara klinis, sekitar 20\% diantaranya masih ditemukan bakteri Salmonella typhi setelah 2 bulan sakit dan sekitar $10 \%$ masih ditemukan pada bulan ke 3 , serta $3 \%$ masih ditemukan setelah 1 tahun. $^{2}$

Kasus carrier meningkat seiring peningkatan umur dan adanya penyakit kandung empedu, serta gangguan traktus urinarius. Kasus tifoid dengan kuman Salmonella typhi masih dapat ditemukan di feces atau urine selama 2-3 bulan disebut carier pasca sembuh. Penelitian di Jakarta melaporkan 16,18\% ( $\mathrm{N}=69)$ kasus demam tifoid masih didapatkan bakteri Salmonella typhi pada kultur fecesnya. ${ }^{2}$

Tanaman pare banyak ditemukan di daerah tropis mempunyai banyak manfaat dan sudah tersebar di pelosok daerah, buah sawo termasuk tanaman daratan rendah yang mudah di dapatkan di daerah seluruh Indonesia. Pare sering diolah menjadi sayuran sedangkan buah sawo di konsumsi secara langsung atau minuman jus. 3,4,5,6

Penelitian oleh Susanto dan Sayekti tentang efektifitas kombinasi buah sawo dan pare pada hewan coba mencit menunjukkan hasil yang signifikan dalam menghambat pertumbuhan bakteri Salmonella typhi. ${ }^{3}$ Selain itu, penelitian Susanto tentang pengaruh perasan buah sawo pada usus halus mencit menunjukkan hasil yang bermakna pada pertumbuhan bakteri Salmonella typhi. ${ }^{7}$

Berdasarkan latar belakang tersebut peneliti ingin menguji kandungan antimikroba kombinasi dari kedua buah tersebut pada bakteri Salmonella typhi hasil isolasi pada carrier penyakit demam typhoid sebagai upaya pencegahan penyebaran bakteri Salmonella typhi dan penelitian tahap selanjutnya dapat dijadikan obat alami terhadap penderita demam typoid maupun carrier baik dalam bentuk produk maupun dalam penyajian alami yang murah dan disukai. Penelitian ini bertujuan untuk mengetahui kombinasi ekstrak buah sawo manila dan pare yang efektif dalam menghambat pertumbuhan bakteri Salmonella typhi

\section{METODE}

Penelitian dilaksanakan pada bulan Februari sampai dengan Oktober 2020. Penelitian dilakukan di Laboratorium Bakteriologi STIKes ICMe Jombang. Jenis penelitian true eksperimental dengan desain penelitian pre-post test group desaign control. Populasi dalam penelitian ini adalah bakteri Salmonella typhi dengan sampel yang diambil dari mahasiswa STIKes ICMe 
Jombang yang didiagnosis sebagai typoid carrier. Tahapan penelitian berupa pengambilan sampel feces dari carrier selanjutnya ditanam pada media SSA dan dilanjutkan uji biokimia dengan media TSIA. Teknik sampling: incidental sampling. Variabel independen dalam penelitian ini adalah kombinasi ekstrak buah pare dan sawo. Sedangkan variabel dependen dalam penelitian ini adalah pertumbuhan bakteri Salmonella typhi dari carrier tifoid.

\section{Alat dan Bahan}

Bahan yang dibutuhkan dalam penelitian ini antara lain medium pembiakan bakteri berupa Nutrin Agar (NA), Nutrien Brot (NB), SSA, MHA, Triptopan Soy Iron Agar (TSIA); aquades steril, aquades, buah Pare dan buah sawo, pewarnaan gram, etanol. Alat yang digunakan dalam penelitian ini adalah cawan petri, tabung reaksi, rak tabung reaksi, penjepit tabung reaksi, erlenmeyer, gelas ukur, gelas beker, pipet volume, trigalski, batang pengaduk, mistar, bunsen, pinset, vortex mixer, $\mathrm{pH}$ meter, gelas benda, kaca penutup, mikroskop binokuler, timbangan analitik, magnetic stirrer, hotplate stirrer, autoklaf, inkubator, refrigerator, kertas payung, alumunium foil, spidol marker, cotton buut, masker, handscoon, dan kertas label.

\section{Pembuatan Ekstrak Buah Pare dan Sawo}

Pembuatan ekstrak sawo dan pare dengan metode maserasi dengan tahapan awal menyiapkan buah pare dan sawo kemudian mencuci sampai bersih. Dilakukan pengeringan menggunakan oven dengan suhu $50^{\circ} \mathrm{C}$ selama 1-2 hari. Setelah sampel kering dihancurkan menggunakan blender sampai menjadi bubuk (simplia). Sebanyak 200 gram sebuk dilakukan maserasi dengan merendam dengan pelarut etanol selama 2 hari dalam keadaan tertutup dengan aluminium foil agar tidak terjadi penguapan dan akan mendapatkan hasil yang sempurna. Selajutnya sampel disaring dengan menggunakan kertas saring. Selanjutnya sampel diletakkan di rorator evaporatory dengan suhu $40^{\circ} \mathrm{C}$ selama 4 jam untuk memisahkan pelarut dengan ekstrak dan mendapatkan ektrak etanol yang pekat. Pengenceran dilakukan dengan perbandingan ekstrak buah pare dan sawo dengan aquades dengan konsentrasi $25 \%$, $50 \%, 75 \%$ dan $100 \%$.

\section{Isolasi Kultur bakteri}

Bakteri yang digunakan adalah Salmonella typhi yang di isolasi dari carrier tifoid pada mahasiswa STIKes ICMe Jombang. Setelah dilakukan isolasi dan identifikasi pada media SSA, setelah itu dilakukan uji penegasan dengan melakukan penanaman pada media TSIA untuk uji biokimia sebagai tahapan memastikan bakteri merupakan bakteri Salmonella typhi. Setelah dapat memastikan maka akan dilakukan sub kultur pada media NA yang sudah disiapkan. Bakteri di simpan di kulkas laboratorium, kemudian ketika akan digunakan untuk perlakuan, maka bakteri di tanam pada media NB dan di inkubasi selama 24 jam.

\section{Pengujian Antimikroba}

Pengujian antibakteri dilakukan untuk melihat ekstrak yang mempunyai efektivitas paling efektif sebagai antibakteri Salmonella typhi dengan metode dilusi padat. Pengujian antibakteri menggunakan kelompok perlakuan sebanyak 5 kelompok dengan ulangan 3 pada masing-masing perlakuan yaitu kelompok kontrol yang tidak dikenai perlakuan atau kelompok kontrol negatif, kelompok kontrol yang diberi bakteri Salmonella typhi saja, kelompok yang diberi ekstrak dengan konsentrasi 25\%, 50\%, 75\%, dan 100\%. Setelah 24 jam diinkubasi di inkubator, selanjutnya dilakukan perhitungan jumlah koloni dengan ketentuan satu koloni berasal dari satu bakteri.

\section{Teknik Pengumpulan Data}

Media cawan petri di inkubasi pada inkubator dengan suhu $37^{\circ} \mathrm{C}$ selama 24 jam dilakukan perhitungan koloni bakteri dengan colony counter. Penyajian data dalam 
penelitian ini akan disajikan dalam bentuk tabel dan diagram.

\section{Analisa Data}

Data yang diperoleh akan dianalisis dengan uji Kruskall Wallis dan untuk menegathui prebedaan antar kelompok maka dilanjutkan dengan uji Mann Withney.

\section{HASIL PENELITIAN}

\section{Data Penelitian}

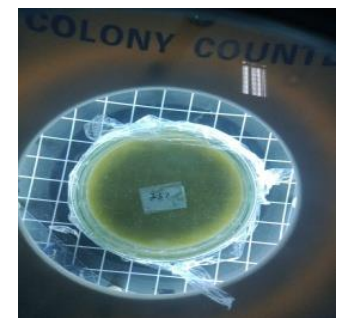

A

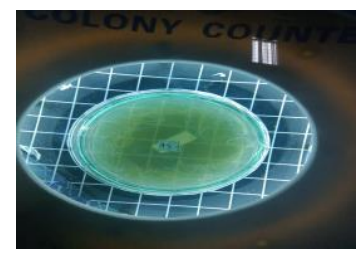

C

Keterangan: A [konsentrasi 25\%], B [konsentrasi 50\%], C [konsentrasi 75\%], D [konsentrasi 100\%]

\section{Gambar 1. Pertumbuhan bakteri Salmonella typhi pada media MHA dan sedang dilakukan perhitungan jumlah koloni menggunakan colony counter.}

Data hasil perhitungan pertumbuhan jumlah bakteri Salmonella typhi dapat dilihat pada tabel 1. Berdasarkan tabel 1 menunjukkan jumlah pertumbuhan bakteri menunjukkan hasil rata-rata kelompok kontrol diatas jumlah syarat hitung, sehingga di tulis sebanyak 300 koloni bakteri, sedangkan pada kelompok perlakuan dengan ekstrak sebesar $100 \%$ tidak terdapat pertumbuhan bakteri, begitu juga dengan konsentrasi $75 \%$. Kelompok perlakuan ekstrak $50 \%$ terdapat pertumbuhan bakteri dengan rata-rata 33,3. Pada konsentrasi terendah $25 \%$ terdapat pertumbuhan bakteri rata-rata 135 .

Berdasarkan pengujian dengan Kruskal Wallis angka sig. sebesar 0.018, terdapat perbedaan antar kelompok perlakuan. Antar Kelompok perlakuan mana yang berbeda, selanjutnya dilakukan uji Mann Withney yang ditunjukkan pada tabel 2.

Tabel 2. Hasil Uji Mann Whitney Efektifitas Ekstrak Buah Pare dan Sawo dengan berbagai konsentrasi

\begin{tabular}{lll}
\hline No. & Kelompok & Sig. \\
\hline 1 & $\mathrm{~A}$ & $\mathrm{~A}^{\mathrm{b}, \mathrm{c}, \mathrm{de}}$ \\
2 & $\mathrm{~B}$ & $\mathrm{~B}^{\mathrm{d}, \mathrm{e}}$ \\
3 & $\mathrm{C}$ & $\mathrm{C}^{\mathrm{d}, \mathrm{e}}$ \\
4 & $\mathrm{D}$ & $\mathrm{D}^{\mathrm{e}}$ \\
5 & $\mathrm{E}$ & $\mathrm{E}$ \\
\hline
\end{tabular}

Keterangan:

A: kelompok Kontrol

B: kelompok ekstrak konsentrasi $25 \%$

C: kelompok ekstrak konsentrasi 50\%

D: kelompok ekstrak konsentrasi $75 \%$

E: kelompok ekstrak konsentrasi $100 \%$

Berdasarkan tabel 2 menunjukkan terdapat perbedaan antar masing-masing kelompok perlakuan, masing-masing berbeda secara nyata sehingga dapat di jelaskan bahwa masing-masing kelompok perlakuan ekstrak konsentrasi 100\%, 75\%, $50 \%, 25 \%$ berbeda secara nyata.

Tabel 1. Hasil Perhitungan Jumlah Bakteri Salmonella typhi Pada Tiap Kelompok Perlakuan Pada Uji Dilusi Padat

\begin{tabular}{ccccccc}
\hline No./ Ulangan & \multicolumn{5}{c}{$\begin{array}{c}\text { Kelompok Perlakuan Ektrak } \\
\text { Koloni Bakteri cfu/ml }\end{array}$} \\
\cline { 2 - 7 } & Control & $\mathbf{1 0 0 \%}$ & $\mathbf{7 5 \%}$ & $\mathbf{5 0 \%}$ & $\mathbf{2 5 \%}$ \\
1. & 300 & 0 & 0 & 34 & 125 & \\
2. & 300 & 0 & 0 & 29 & 142 & \\
3. & 300 & 0 & 0 & 37 & 138 & \\
Rata-rata & 300 & 0 & 0 & 33.3 & 135 & \\
\hline
\end{tabular}




\section{PEMBAHASAN}

Berdasarkan uji Kruskal Wallis menunjukkan perbedaan antar perlakuan secara signifikan $(\mathrm{p}=0,018) \quad$ dapat disimpulkan ada perbedaan antara kelompok perlakuan, baik kelompok kontrol, kelompok 25\%, kelompok 50\%, kelompok $75 \%$ maupun kelompok $100 \%$. Hasil uji antar kelompok (Tabel 2) terdapat perbedaan antar masing-masing kelompok perlakuan secara signifikan.

Dalam penelitian Komalasari, dkk yang menggunakan etanol $70 \%$ dengan berbagai macam konsentrasi ekstrak pare (Momordica charantia L) menunjukkan efektivitas pada konsentrasi $75 \%$, namun lemah dalam menghambat pertumbuhan bakteri Salmonella typhi, karena masih terbentuk koloni-koloni bakteri. ${ }^{8}$

Kandungan senyawa pada buah pare dan buah sawo berupa flavonoid, saponin, alkaloid dan polifenol. Mekanisme flavonoida dalam membunuh bakteri dengan cara mengganggu aktivitas transpeptidase peptidoglikan, sehingga pembentukan dinding sel bakteri terganggu dan sel bakteri mengalami lisis. Hal ini sama dengan penelitian oleh Malina bahwa golongan senyawa flavonoid dapat mendenaturasi protein yang menyebabkan aktivitas metabolisme sel bakteri berhenti. ${ }^{9}$ Ketersediaan alkaloid dapat mengganggu terbentuknya komponen-komponen penyusun peptidoglikan pada sel bakteri, yang mengakibatkan sel bakteri mengalami lisis.

Senyawa lainnya yaitu terpenoid dapat menyebabkan lisisnya bakteri dengan cara mengikat protein, lipid dan atau karbohidrat yang terdapat pada membran sel. Senyawa polifenol dan tanin dapat menghambat aktivitas enzim protease, menghambat enzim pada protein transpor selubung sel bakteri dan destruksi atau in aktivasi fungsi materi genetic bakteri. Tanin juga dapat mengkerutkan permukaan dinding sel bakteri sehingga mengganggu aktifitas permeabilitas sel bakteri. Terganggunya permeabilitas sel bakteri menyebabkan sel tersebut tidak dapat melakukan aktivitas hidup sehingga pertumbuhannya terhambat atau mati. ${ }^{8}$

Sebagai tambahan menurut Cushnie et al. dalam Komalasari ada tiga mekanisme yang dimiliki flavonoid dalam memberikan efek antibakteri, antara lain dengan menghambat sintesis asam nukleat, menghambat fungsi membrane sitoplasma dan menghambat metabolisme energi. ${ }^{8}$ Sedangkan menurut Karlina et al. bahwa saponin dapat menekan pertumbuhan bakteri, karena senyawa tersebut dapat menurunkan tegangan permukaan dinding sel bakteri, selanjutnya berinteraksi dengan dinding sel bakteri maka dinding tersebut akan mengalami pecah atau lisis. ${ }^{10}$ Saponin akan mengganggu tegangan permukaan pada dinding sel, maka saat tegangan permukaan terganggu zat anti bakteri masuk dengan mudah kedalam sel dan mengganggu metabolisme hingga akhirnya terjadilah kematian bakteri.

\section{KESIMPULAN}

Kesimpulan bahwa kombinasi ekstrak buah pare dan sawo manila efektif dalam menghambat pertumbuhan bakteri Salmonella typhi yang di isolasi dari carrier penderita tipus pada konsentrasi terendah sebesar $25 \%$.

\section{UCAPAN TERIMA KASIH}

Peneliti mengucapkan terima aksih
kepada RistekDikri yang telah
memberikandana untuk penelitian ini
melalui PDP Tahun Anggaran 2020,
Sekolah tinggi Ilmu Kesehatan Insan
Cendekia Medika Jombang yang turut
memfasilitasi dan semua pihak yang telah
membantu.

\section{DAFTAR PUSTAKA}

1. Librianty, N. Panduan Mandiri Melacak Penyakit. Jakarta: Lintas Kata . (2015). 
2. Irianto, Koes. Mikrobiologi Medis, PP.71-3, Penerbit Alfabeta, Bandung. (2013).

3. Rizki, F. (2013). The Miracle of Vegetables. Jakarta; AgroMediaPustaka.

4. Subahar, T. S. S. (2008). Khasiat \& Manfaat Pare, si Pahit Pembasmi Penyakit. Jakarta; Agro MediaPustaka

5. Suwarto, A. (2010). 9 Buah dan Sayur Sakti Tangkal Penyakit. Yogyakarta : Liberplus

6. Wirakusumah, E. S. (2007). Jus Buah Dan Sayuran. Jakarta: Penebar Swadaya.

7. Susanto A, Sayekti S. (2018) Efektifitas Kombinasi Ekstrak Buah PARE (Momordica charantia) Dan Sawo Manila (Manilkara zapota) Terhadap Pertumbuhan Bakteri Salmonella typhi Secara In Vivo Pada Usus Halus Mencit. PDP Kemenristekdikti, Jurnal Insan Cendekia, Vol. 8 no.1 September 2018.
8. Susanto A. 2018. Pengaruh pemberian ekstrak buah sawo manila (Manilkara zapota) terhadap pertumbuhan bakteri Salmonella typhi pada usus halus mencit. Prosiding Seminar Nasional 1, tahun 2017. ISBN 978-602-51139-0-1. STIKes Majapahit Mojokerto. URL: https://stikesmajapahit.ac.id/downlo.

9. Komalasari, dkk. Uji Efektivitas Ekstrak Etanol Buah Pare (Momordica charantia L) Sebagai Antibakteri Salmonella typhi. Fitofarmaka, Vol. 2 No.1, Juni 2012 :36-41. (2012).

10. Malina, dkk. Aktivitas Antibakteri Kulit Garcinia mangostana Linn. Terhadap Pertumbuhan Flavobacterium dan Enterobacter dari Coptotermes curvignathus holmgren. Protobiont Vol 2 (1), 7-11. (2013).

11. Karlina C.Y, Ibrahim M, Trimulyono G. Aktivitas Antibakteri Ekstrak Herba Krokot (Portulaca oleracea L.) terhadap Staphylococcus aureus dan Escherichia coli. E journal UNESA LenteraBio. 2 (1):87-93. 2013 